\title{
Effect of different nutrient formulations on growth and yield of Cordyline fruticosa grown in soilless culture system
}

\author{
S Vishnupandi \& T Thangaselvabai
}

Journal of Agriculture and Ecology

Volume-8 (December, 2019)

ISSN: 2456-9410

\section{Journal of Agriculture} and Ecology

ISSN: 2456-9410

Volume: 8

Journal of Agriculture and Ecology (2019) 8: 24-29 http://doi.org/10.53911/JAE.2019.8203 


\title{
Effect of different nutrient formulations on growth and yield of Cordyline fruticosa grown in soilless culture system
}

\author{
S Vishnupandi $\square \&$ T Thangaselvabai \\ Department of Floriculture and Medicinal Crops, Horticultural College and Research Institute, \\ Periyakulam- 625604 \\ Tamil Nadu Agricultural University, Coimbatore - 641003 \\ $\square$ Corresponding author: S Vishnupandi, Email: vishnuvimal44@gmail.com
}

\section{Article Info}

Article history

Received: 15 September 2018

Accepted: 10 November 2018

Available online: 5 August 2019

Key Words: Cut foliage, Cordyline fruticosa, Soilless culture system, Hoagland and Arnon nutrient formulation.

\begin{abstract}
Cut foliages are an important component of the floricultural industry, largely used in decoration as filler in floral compositions. They provide freshness, colour and variety to arrangements and bouquets. Cordyline fruticosa is an important cut green in the world trade and used worldwide for its beautiful foliage.The increasing demand for the production of quality cut foliages pressurizes the flower growers to adopt advanced technologies even under poor resource conditions. Soilless culture is one such production system that involves precise control of nutrition and efficient use of water, which in turn resulted in quality produce commanding premium price in the market. Owing to the above demand, the present investigation was carried out during 2017-18 at Horticultural College and Research Institute, Periyakulam to determine the effect of different nutrient formulations on growth and yield of Cordyline fruticosa grown in soilless culture system. Eight nutrient formulations were tested for its efficacy along with rain water as control and observations on growth and yield parameters were recorded. The results of the study revealed that Hoagland and Arnon- nutrient formulation increased growth and yield parameters of Cordyline fruticosa grown in soilless culture system.
\end{abstract}

Copyright @2019 Vishnupandi \& Thangaselvabai, This is an open access article published under the terms of the Creative Commons Attribution License, which permits unrestricted use, distribution, and reproduction in any medium, provided the original work is properly cited.

Preferred citation: Vishnupandi S \& Thangaselvabai T. 2019. Effect of different nutrient formulations on growth and yield of Cordyline fruticosa grown in soilless culture system. Journal of Agriculture and Ecology, 8: 24-29; http://doi.org/10.53911/JAE.2019.8203.

\section{Introduction}

The floriculture industry involves the production and distribution of loose flowers, cut flowers and foliage, and ornamental plants to meet out the demand of the domestic and international market. Cut foliage is vegetation used in large quantities as a source of decoration on its own or in association with flowers in bouquets. Cordyline belongs to the family Asparagaceae and commonly called as luck plant or cabbage palm is a tropical ornamental with high decorative value due to 
its variety of colors and foliar patterns. The increasing demand for the production of quality cut foliages pressurizes the flower growers to adopt advanced technologies even under poor resource conditions. Hydroponics is the fastest growing sector of agriculture/horticulture, and it could very well dominate crop production in the future. Soilless culture can provide important requirements for plant growth with equal growth and yield results compared to soil. Nutrients play a very important role in obtaining quality foliage/flowers. The soil less culture involves precise control of nutrition and efficient use of water, which in turn results in quality produce commanding premium price in the market. Keeping this in view, the present investigation was carried out to determine the effect of different nutrient formulations on growth, yield and postharvest quality of Cordyline fruticosa grown in soilless culture system.

\section{Materials and Methods}

In this study, three months old plants of Cordyline fruticosa were planted in a plastic container containing different nutrient formulations. An open soilless culture system, which was irrigated and nourished by drip irrigation system, was used. The study was carried out during 2017-18 at Horticultural College and Research Institute, Periyakulam in Completely Randomized Block Design with nine treatments and three replications. The treatment consists of eight nutrient formulations according to cited works (Hoagland \& Arnon 1950; Hewitt 1966; Colakoglu-1and 2 2005; Steiner 1984; Bollard 1966; Middleton \& Toxopeus 1966) and water soluble fertilizer (19:19:19) along with rain water as control. The $\mathrm{pH}$ of the irrigation water was measured and set between 5.5 and 6.5 in all treatments (Ozzambak \& Zeybekoglu 2004). Similarly, the EC of nutrient formulations was maintained between 1.5 to $2.5 \mathrm{dSm}^{-1}$ (Sonneveld \& Voogt 1983) throughout the experiment.

Observations on morphological, physiological and yield parameters such as plant height $(\mathrm{cm})$, number of leaves, leaf area $\left(\mathrm{cm}^{2}\right)$, leaf longevity (days), Chlorophyll $(\mathrm{mg} / \mathrm{g})$, anthocyanin $(\mathrm{mg} / \mathrm{g})$ and yield were observed at 90 days after planting. The recorded data was subjected to statistical analysis (Panse 1954).

\section{Results and Discussion}

\section{Effect of different nutrient formulations on morphological parameters}

The production of quality foliage plants in soilless culture can be attained by the use of proper nutrient formulations, which have a prominent effect on growth. In the present study among the different nutrient formulations tested, Hoagland and Arnonnutrient formulation $\left(\mathrm{T}_{2}\right)$ recorded significantly the highest plant height (52.46 $\mathrm{cm})$, number of leaves(12.33), leaf area $\left(207.16 \mathrm{~cm}^{2}\right)$, leaf longevity (28.50 days) and leaf production interval (9 days) in Cordyline fruticosa at 90 days after planting, while the lowest plant height $(52.46 \mathrm{~cm})$, number of leaves (8.47), leaf area $\left(145.97 \mathrm{~cm}^{2}\right)$, leaf longevity (21.50 days) and leaf production interval (14 days) was recorded in $\mathrm{T}_{1}$ (control) (Table.1). The healthy and robust vegetative frame is an essential pre-requisite for high 
vegetative growth. Major food manufacturing units in plants are leaves and the growth of them is chiefly influenced by given plant nutrient status. The increased vegetative growth in the Hoagland and Arnon- nutrient formulation may be due to the balanced availability and release of essential nutrients which enhances the uptake of nutrients, increase the assimilation capacity and ultimately the crop growth. The absorbed nitrogen ultimately lead to the formation of complex nitrogenous substances such as proteins/ amino acids to build up new tissues and thereby nitrogen greatly influenced the leaf growth, leaf area and photosynthetic rate. Longevity of leaves in a plant depends on the environmental conditions, nutrient status of the plants and genetic factors. Calcium is responsible for holding together the cell walls of plantsactivating certain enzymes and to send signals that coordinate certain cellular activities that produce quality leaves with maximum longevity on plant. The promotive effect of Hoagland and Arnon- nutrient formulation on morphological characters are in accordance with the findings of Kilinc et al. (2007) in fig saplings; A (2012) in Beta vulagaris; Li \& Cheng (2014) in cucumber seedling; Mohidin et al. (2015) in oil palm seedling; Azeezahmed et al. (2016) in chrysanthemum grown under soilless culture system; Sabareeswaran et al. (2018) in plantlets of Dendrobium var. Thongchai Gold.

Table 1. Effect of different nutrient formulations on growth of Cordyline fruticosa grown in soilless culture system

\begin{tabular}{ccccccc}
\hline $\begin{array}{c}\text { S. } \\
\text { No }\end{array}$ & Treatment & $\begin{array}{c}\text { Plant } \\
\text { height } \\
(\mathrm{cm})\end{array}$ & $\begin{array}{c}\text { No. of } \\
\text { leaves per } \\
\text { plant }\end{array}$ & $\begin{array}{c}\text { Leaf area } \\
\left(\mathrm{cm}^{2}\right)\end{array}$ & $\begin{array}{c}\text { Leaf } \\
\text { longevity } \\
\text { (days) }\end{array}$ & $\begin{array}{c}\text { Leaf production } \\
\text { interval (days) }\end{array}$ \\
\hline 1. & $\mathrm{~T}_{1}$ & 38.77 & 8.47 & 145.97 & 21.50 & 14.00 \\
2. & $\mathrm{~T}_{2}$ & 52.46 & 12.33 & 207.16 & 28.50 & 9.00 \\
3. & $\mathrm{~T}_{3}$ & 51.26 & 10.00 & 192.73 & 25.00 & 9.20 \\
4. & $\mathrm{~T}_{4}$ & 42.15 & 8.67 & 148.60 & 22.60 & 12.40 \\
5. & $\mathrm{~T}_{5}$ & 49.50 & 9.33 & 190.27 & 24.00 & 10.20 \\
6. & $\mathrm{~T}_{6}$ & 48.56 & 9.60 & 178.25 & 23.20 & 11.60 \\
7. & $\mathrm{~T}_{7}$ & 46.28 & 8.73 & 163.21 & 23.00 & 11.80 \\
8. & $\mathrm{~T}_{8}$ & 51.26 & 10.67 & 189.64 & 26.20 & 940 \\
9. & $\mathrm{~T}_{9}$ & 49.60 & 10.40 & 183.28 & 24.30 & 9.20 \\
\hline & $\mathrm{Mean}$ & 47.76 & 9.80 & 177.68 & 24.26 & 10.80 \\
& $\mathrm{SEd}$ & 1.026 & 0.625 & 3.259 & 0.576 & 0.178 \\
& $\mathrm{CD}(0.05)$ & 2.152 & 1.319 & 6.833 & 1.201 & 0.381 \\
\hline
\end{tabular}

Effect of different nutrient formulations on physiological parameters

In the present study among the different nutrient formulations tested, Hoagland and Arnon- nutrient formulation $\left(\mathrm{T}_{2}\right)$ recorded significantly the highest chlorophyll content $(1.64 \mathrm{mg} / \mathrm{g})$, soluble protein $(72.35 \mathrm{mg} / \mathrm{g})$ and anthocyanin content $(12.8 \mathrm{mg} / \mathrm{g})$ in Cordyline fruticosa at 90 days after planting, while the lowest chlorophyll content $(1.12 \mathrm{mg} / \mathrm{g})$, soluble protein $(62.83$ $\mathrm{mg} / \mathrm{g})$ and anthocyanin content $(8.14 \mathrm{mg} / \mathrm{g})$ was recorded in $\mathrm{T}_{1}$ (control) (Table.2). 
Chlorophyll is the main pigment that takes part in photosynthesis, which is an essential process of plant system and also its growth and development. The increased accumulation of nutrients especially $\mathrm{N}, \mathrm{Mg}, \mathrm{K}$ can result in increased pigment synthesis or low rate of degradation of chlorophyll content. This also have a beneficial effect on phloem loading and probably also on the mobilization of photosynthates deposited in the leaves. The highest soluble protein content of cordyline plants grown in Hoagland and Arnon- nutrient formulation $\left(\mathrm{T}_{2}\right)$ may be due to the enhancement of photosynthetic pigment and the assimilates produced by the pigment. Anthocyanin is one of the most conspicuous classes of flavonoids together with proanthocyanidins and flavonols are important plant pigments responsible for the red, pink, purple and blue colours in plants (Grotewold 2004). It can protect chloroplasts from the adverse effects of excess light causing photooxidative damage. Nutrient status in Hoagland \& Arnon nutrient formulation especially $\mathrm{N}$, may be employed to manipulate the anthocyanin content of vegetative tissues of cordyline plants. The results are in accordance with Stewart et al. (2000) in tomato; Khalaj et al. (2011) in gerbera; A (2012) in Beta vulgaris; Li \& Cheng (2014) in cucumber seedlings; Mohidin et al. (2015) in oil palm seedlings grown under soilless culture system.

Table 2. Effect of different nutrient formulations on physiological parameters of Cordyline fruticosa grown in soilless culture system

\begin{tabular}{|c|c|c|c|c|}
\hline S. No & Treatment & $\begin{array}{c}\text { Chlorophyll } \\
(\mathrm{mg} / \mathrm{g})\end{array}$ & $\begin{array}{l}\text { Soluble protein } \\
(\mathrm{mg} / \mathrm{g})\end{array}$ & $\begin{array}{l}\text { Anthocyanin } \\
(\mathrm{mg} / \mathrm{g})\end{array}$ \\
\hline 1 & $\mathrm{~T}_{1}$ & 1.12 & 62.83 & 8.14 \\
\hline 2 & $\mathrm{~T}_{2}$ & 1.64 & 72.35 & 12.8 \\
\hline 3 & $\mathrm{~T}_{3}$ & 1.47 & 69.79 & 10.82 \\
\hline 4 & $\mathrm{~T}_{4}$ & 1.26 & 63.88 & 9.22 \\
\hline 5 & $\mathrm{~T}_{5}$ & 1.45 & 69.62 & 10.24 \\
\hline 6 & $\mathrm{~T}_{6}$ & 1.42 & 61.91 & 9.76 \\
\hline 7 & $\mathrm{~T}_{7}$ & 1. & 66.76 & 9.34 \\
\hline 8 & $\mathrm{~T}_{8}$ & 1.53 & 70.52 & 11.64 \\
\hline 9 & $\mathrm{~T}_{9}$ & 1.46 & 68.69 & 10.68 \\
\hline & Mean & 1.4 & 68.03 & 10.29 \\
\hline & SEd & 0.02 & 1.258 & 0.143 \\
\hline & $\mathrm{CD}(0.05)$ & 0.050 & 2.645 & 0.306 \\
\hline \multicolumn{3}{|c|}{$\begin{array}{l}\text { Effect of different nutrient formulations on } \\
\text { yield and vase life }\end{array}$} & \multirow{2}{*}{\multicolumn{2}{|c|}{$\begin{array}{l}\text { control }\left(\mathrm{T}_{1}\right)((\text { Table } 3 \& \text { Fig } 1) \text {. High yield } \\
\text { quality crops can be obtained by supplying } \\
\text { optimum mineral nutrition. Mineral nutrition } \\
\text { of Hoagland and Arnon- nutrient formulation } \\
\text { involves the supply, absorption and utilization } \\
\text { of the essential nutrients required for } \\
\text { successful growth and assimilation of } \\
\text { metabolites and hence for the yield of the crop }\end{array}$}} \\
\hline $\begin{array}{l}\text { formula } \\
\text { formula } \\
\text { maximu } \\
(10.67 \mathrm{~d} \\
\text { and vas }\end{array}$ & $\begin{array}{l}\text { the differ } \\
\text { gland and } A \\
\text { exhibited si } \\
7.67 \text { leave } \\
\text { ninimum yie } \\
0 \text { days) wa }\end{array}$ & $\begin{array}{l}\text { nutrient } \\
\text { - nutrient } \\
\text { antly the } \\
\text { vase life } \\
67 \text { leaves) } \\
\text { served in }\end{array}$ & & \\
\hline
\end{tabular}


plants. Vase life is the period during which cut foliage retains its appearance in a vase. Plants having more vase life are most preferable. This is because of better nutrient status, metabolites and lower transpiration rate affected by the nutrient formulation. The results of this study are supported by the findings of Favero et al. (2011) in cordyline.

Table 3. Effect of different nutrient formulations on leaf longevity (days) and yield (number of leaves) of Cordyline fruticosa grown in soilless culture system

\begin{tabular}{lccc}
\hline S. No & Treatment & Yield (number of leaves) & Vase life (days) \\
\hline 1. & $\mathrm{~T}_{1}$ & 4.33 & 7.00 \\
2. & $\mathrm{~T}_{2}$ & 7.67 & 10.67 \\
3 & $\mathrm{~T}_{3}$ & 6.33 & 8.67 \\
4. & $\mathrm{~T}_{4}$ & 4.67 & 7.67 \\
5. & $\mathrm{~T}_{5}$ & 5.67 & 8.33 \\
6. & $\mathrm{~T}_{6}$ & 5.00 & 8.00 \\
7. & $\mathrm{~T}_{7}$ & 5.00 & 7.67 \\
8. & $\mathrm{~T}_{8}$ & 6.67 & 9.33 \\
9. & $\mathrm{~T}_{9}$ & 6.33 & 7.00 \\
\hline & $\mathrm{Mean}$ & 5.74 & 8.26 \\
& $\mathrm{SEd}$ & 0.497 & 0.471 \\
& $\mathrm{CD}(0.05)$ & 1.049 & 0.994 \\
\hline
\end{tabular}

Fig 1. Effect of different nutrient formulations on yield (number of leaves) of Cordyline fruticosa grown in soilless culture system

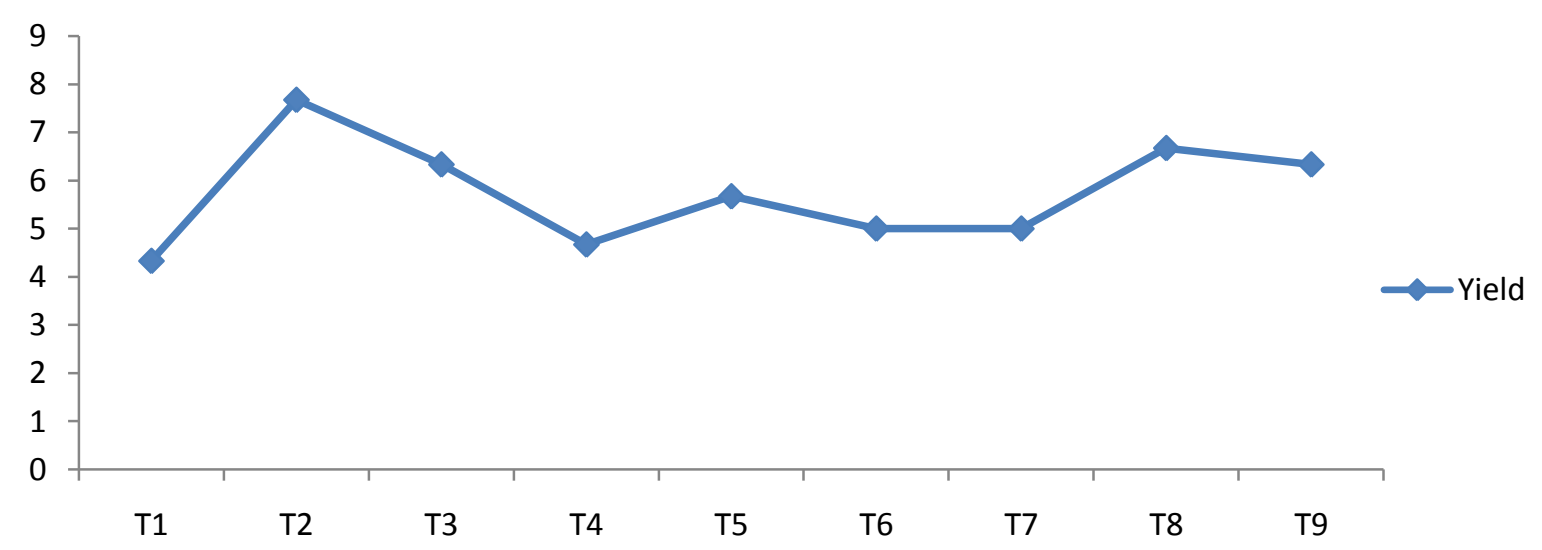

\section{Conclusion}

From the investigation, Hoagland and Arnon- nutrient formulation was found to be the best formulation, as it recorded the highest performance in growth, physiological and yield parameters. Present results might be the first step for determining the best formulation for cordyline leaf production in soilless culture. However, further research is definitely necessary to obtain more comprehensive results, since only a limited number of nutrient formulations were tested.

Acknowledgements

The authors are grateful to all department members for helping throughout the research programme. 


\section{References}

A DB. 2012. Effects of different combinations of Hoagland's solution and Azolla filiculoides on growth and development of Beta vulgaris subsp. cycla 'Fordhook Giant' grown in hydroponic cultures. International Journal of the Physical Sciences, 7(33) doi: 10.5897/ijps 12.320.

Azeezahmed SK, Dubey RK, Kukal SS \& Sethi VP. 2016. Effect of different nitrogen-potassium concentrations on growth and flowering of chrysanthemum in a drip hydroponic system. Journal of Plant Nutrition, 39(13), 1891-1898. doi: 10.1080/01904167.2016.1187749.

Favero B, Carmello Q \& Dias G. 2011. Vase life of new tropical cut foliage: Cordyline terminalis. Paper presented at the IV International Conference Postharvest Unlimited 2011945.

Grotewold E. 2004. The challenges of moving chemicals within and out of cells: insights into thetransport of plant natural products. Planta, 219(5): 906-909.

Hassan I. 2005. Effect of rice straw compost and water regimes on growth performance of tomato (Lycopersicum esculentum L.). PhD thesis. Faculty of Agriculture, Universiti Putra Malaysia Karimaei, M. S., Massiha, S., \& Mogaddam, M. (2004). Comparison of two nutrient solutions $\hat{a} \square \mathrm{TM}$ effect on growth and nutrient levels of lettuce (Lactuca sativa L.) cultivars.

Khalaj MA, Kiani S, Khoshgoftarmanesh AH, \& Amoaghaie R. 2017. Growth, quality, and physiological characteristics of gerbera (Gerbera jamesonii L.) cut flowers in response to different NO3-: $\mathrm{NH} 4+$ ratios. Horticulture, Environment, and Biotechnology, 58(4): 313-323.
Li, H., \& Cheng, Z. (2014). Hoagland nutrient solution promotes the growth of cucumber seedlings under light-emitting diode light. Acta Agriculturae Scandinavica, Section B-Soil \& Plant Science, 65(1): 74-82.

Mohidin H, Hanafi MM, Rafii YM, Abdullah SNA, Idris AS, Man S, Sahebi M. 2015. Determination of optimum levels of nitrogen, phosphorus and potassium of oil palm seedlings in solution culture. Bragantia, 74(3): 247-254.

Ozzambak E \& Zeybekoglu E. 2004. Serada topraksiz gerbera yetiştiriciliği ve bazı yetiştirme ortamlarının karşılaştırılması (araştırma sonuçları): İzmir Ticaret Odas1.

Panse VG. 1954. Statistical methods for agricultural workers: Indian Council of Agricultural Research; New delhi.

Sabareeswaran VS, Swarnapriya R \& Kannan M. 2018. Standardization of growing media for hardening plantlets of Dendrobium var. Thongchai Gold. Journal of Agriculture and Ecology, 6: 64-70.

Sirin U. 2011. Effects of different nutrient solution formulations on yield and cut flower quality of gerbera (Gerbera jamesonii) grown in soilless culture system. African Journal of Agricultural Research, 6(21), 4910-4919.

Sonneveld C. 2002. Composition of nutrient solutions. Hydroponic production of vegetables and ornamentals. Embryo Publications, Athens, Greece, 179-210. 